\title{
XLV Congreso de la Sociedad Española de Enfermería Nefrológica: Nuevos retos de formación
}

\author{
Fernando González, Francisca Pulido, Juan Francisco Pulido, Patricia Arribas \\ Junta Directiva. Sociedad Española de Enfermería Nefrológica (SEDEN)
}

Como citar este artículo: González F, Pulido F, Pulido JF, Arribas P. XLV Congreso de la Sociedad Española de Enfermería Nefrológica: Nuevos retos de formación. Enferm Nefrol. 2020 Jul-Sep;23(3):231-232

Queridos socios:

Iniciamos este nuevo curso con una mezcla de sensaciones que creemos son comunes en cada uno de nosotros.

Se mezcla la amarga experiencia recientemente vivi$\mathrm{da}$, en la que nuestra vida personal y profesional ha sido duramente embestida, con una realidad actual que nos hace estar muy alerta para intentar no volver a vivirlo. Pero a su vez, no nos queda más remedio que vivir con la esperanza de reencontrarnos con la felicidad que estamos seguros todos merecéis.

Como bien sabéis, "nuestra SEDEN" no ha parado su actividad durante la pandemia. Todos los que en su día aceptamos el compromiso de trabajar para ella, hemos intentado mantener su pulso lleno de vida y esto en parte nos ha servido para sentiros cerca como siempre y apoyando vuestra labor y vuestra profesionalidad más que nunca.

Uno de los pilares fundamentales en los que se asienta nuestra querida Sociedad, es la transmisión de conocimientos entre los miembros que la componen. Gran parte de nuestros esfuerzos han de dedicarse a mantener y si es posible, mejorar dicha transmisión. Así, los profesionales de la enfermería nefrológica debemos mantenernos unidos por esta inquietud que sin duda nos hace ser mucho mejores como profesionales y como colectivo.

Es en parte por esto, por lo que todos los años celebramos con todo orgullo nuestro Congreso Nacional.
Celebración anual, que desde esta Junta Directiva consideramos imprescindible.

Al inicio del año en curso, como bien todos sabéis, comenzamos a organizar junto con el Comité Local de la inigualable ciudad de Granada, el que en su día iba a ser nuestro XLV Congreso. Pronto las circunstancias cambiaron por completo el escenario de nuestras vidas y a pesar de la brutal incertidumbre que nos azotaba día a día a todos nosotros, seguimos manteniendo en pie la organización del programa y resto de actividades, por si en algún momento la situación se presentaba como reversible. Que contaros, no sólo no hubo mejoría en la pandemia, sino que todo empeoró. Fue entonces cuando nos vimos obligados a aplazar el Congreso presencial en tierras nazaríes y reinventar la manera de mantener nuestro compromiso con todos vosotros y comenzar a organizar nuestro XLV Congreso Nacional de la SEDEN en formato virtual.

El Congreso Virtual se celebrará entre el 12 y el 15 de noviembre del presente año. Podéis imaginar que para nosotros supone todo un reto y teniendo en cuenta que antes hablábamos de esperanza, se abre una ventana a un nuevo mundo lleno de oportunidades.

Es evidente, que un Congreso Virtual no puede compararse con nuestros Congresos presenciales, en los que se aúna el interés científico y profesional con el calor del abrazo y las miradas cómplices. Aún así, estamos trabajando y ya tenemos diseñado un Congreso que, con cierto nerviosismo, deseamos de todo corazón esté a la altura de lo que deseáis y merecéis. 
Ya se han evaluado los trabajos científicos y tenemos diseñado un programa que esperamos cubra todas las expectativas.

Por otro lado, un Congreso Virtual abre también la ventana a la oportunidad de que en él participen profesionales de otros países cuya presencia es enormemente más difícil cuando se trata de la modalidad presencial. Es decir, creemos que este año seremos más profesionales inscritos y eso siempre es algo muy positivo.

Detrás de la organización del programa científico, los estands, las conferencias, los talleres y todo lo que conlleva nuestro Congreso, se suma este año la enorme complejidad técnica que esperamos cubra todas las necesidades para que todo llegue a vuestras casas o vuestros centros de trabajo con todas las garantías. Por ello, en su día nos asesoramos de que empresas podrían darnos la máxima fiabilidad y ya tenemos contratados todos los servicios que nos apoyen en nuestro nuevo proyecto.

Desde aquí, todo nuestro agradecimiento a los evaluadores, coordinadores, a nuestros Vocales y a todos los que hacéis posible que éste sueño continúe.

$\mathrm{Y}$ a todos vosotros animaros para seguir investigando, no perdáis vuestro sentido crítico. Sois la base de todo. No nos queda más que volver a reiteraros todo nuestro apoyo y nuestra solidaridad y desear que todos os encontréis bien y con fuerzas para sobrellevar lo que el destino nos ponga por delante.

Y como siempre, cuidaros mucho para poder seguir cuidando.

Este artículo se distribuye bajo una Licencia Creative Commons Atribución-NoComercial 4.0 Internacional. https://creativecommons.org/licenses/by-nc/4.0/

Open Access (C) (1) (\$) 